\title{
CLAY STATUETTES OF MALE AND FEMALE PAREDROS FROM ROMAN DACIA
}

\section{RADU OTA}

\author{
National Museum of the Union, Alba Iulia \\ 12-14 Mihai Viteazu Street, \\ RO-510010 Alba Iulia, Romania \\ eractum@yahoo.com
}

\begin{abstract}
This paper synthetises knowledge concerning the spread of the paredros type statuette in Roman Dacia. Thus, we examined their manner of distribution, the workshops, and most importantly their significance. The author notes that these statuettes were discovered solely in Dacia Superior and Porolissensis, especially in the former. He highlights the fact that these statuettes were found in the area of the most developed urban planning, along the Ulpia Traiana Sarmizegetusa-Apulum-Potaissa-Porolissum line, in highly Romanised towns with important military units stationed nearby. Similarly, it shows the important role the Apulum urban centre played in producing and distributing these votive statuettes. The author concludes that these statuettes are additional evidence of the lower classes' affiliation to imperial power. Due to the spread of the Jupiter cult in Apulum, it is no wonder that people sought to obtain a cheaper variant, accessible to the poor. Due to this aspect, as well as the sober, rigid stance of the characters, we attribute them to the deities Jupiter and Juno. Considering that such statuettes were not found in burials, it is unlikely that they were funerary offerings that were more likely to depict the divine couple Pluto and Proserpine. The statuettes cannot represent local Dacian deities since the conquered population is rarely mentioned in provincial inscriptions with anthroponyms (just over two percent), and sculptural or epigraphic monuments do not represent the deities of the ancient local pantheon. Furthermore, in the urban environment where these votive terracottas were produced, the presence of the Thracian-Dacian population is almost never mentioned epigraphically (more than $1 \%$ of epigraphs depict anthroponyms) or archaeologically.
\end{abstract}

Keywords: Apulum, Roman Dacia, enthroned divinities, clay statuettes.

\section{INTRODUCTION}

This paper analyses several statuettes made of burnt clay, depicting two types of figures sitting on thrones, one male the other female. This iconographic form appears only on coroplastic items of Roman Dacia. They were interpreted throughout time by different researchers in diverse ways; however there has never been consensus as to their meaning. We chose to evaluate finds of this type by establishing the areas in which they were identified, the workshops in which they were manufactured, and their significance.

\section{DEPICTION, CHRONOLOGICAL FRAMEWORK, AND MANUFACTURING WORKSHOPS}

The majority of figurines were discovered without mention of their archaeological context. Two characters paredros, one male, one female, are rendered very conceptually, without features. The male character, characteristically seated to the right, has a bushy beard and curly hair. He wears a chlamys that covers his chest. It is fastened with a circular brooch on the right shoulder. His counterpart wears a tunic whose edge is noticeable below the neck while a tiara is visible on her head. The throne has twisted armrests and a high back. A small mark, slightly in relief, 
separates the two deities. Rigidity and sketchiness characterise these images. The lower limbs are not depicted. In fact, they resemble an illustration or an image, an iconographic scheme to be acknowledged and followed by the worshippers. Pieces of this type have no dating value based on their stylistic features. Some were found alongside other objects that help establish the chronological context. Others were retrieved from an archaeological context, following field research.

One of these statuettes, misinterpreted by the second editor as a bas-relief, ${ }^{1}$ was discovered in the military vicus of Porolissum, in the dwelling of a veteran, in 1909. The figurine was found next to a fragment of a military diploma and a silver appliqué depicting an aquila. ${ }^{2}$ The official document contains a significant recognition of Dacia Porolissensis dating to $29^{\text {th }}$ of June, AD 120. It belonged to an eastern archer of Syrian origin, Hamaseus Alapata, who was part of the numerus Palmyrenorum Porolissensium. ${ }^{3}$ Thus, this statuette from Porolissum appears in a context from the first half of the $2^{\text {nd }}$ century AD. Moreover, these examples of provincial coroplastics were manufactured in Dacia, at the beginning of the time of Hadrian.

The second statuette (H: $12 \mathrm{~cm} ; \mathrm{W}: 5.6 \mathrm{~cm})$ was found in a villa suburbana, south of the municipium Septimium Apulense in 2004, in Monolit in an archaeological context dated between the end of the $2^{\text {nd }}$ century and the first decades of the $3^{\text {rd }}$ century AD (Fig. 1). ${ }^{4}$ In this place an interesting altar dedicated to Terra Mater by the physician Septimius Asclepius Hermes was also found. ${ }^{5}$ A third one $(\mathrm{H}: 8.1 \mathrm{~cm}$; W: $3.2 \mathrm{~cm})$ was discovered in the northwestern area of municipium Septimium Apulense, the second Roman town of Apulum, in 25 T. Cipariu Street, in a complex dated following the middle of the $3^{\text {rd }}$ century AD, based on a suberate antoninus issued after 244 (Fig. 2). ${ }^{6}$ The fourth statuette of paredros preserving only the upper part with the characters' heads and a part of the throne's back $(\mathrm{H}: 8.60 \mathrm{~cm}, \mathrm{~W}: 10.30 \mathrm{~cm})$, revealed by the construction works of the Wastewater Treatment Plant from Alba Iulia in 2013, in an area west of the first Roman town of Apulum, colonia Aurelia Apulensis, in a building (villa suburbana) dated following the middle of $3^{\text {rd }}$ century AD based on a denarius issued by Valerianus in 253 (Fig. 3). Two other pieces of the type, fragmentary, were retrieved from archaeological excavations conducted at the installation of a water pipe, east of colonia Aurelia Apulensis, in extramuros zone (villa suburbana) in 2015. The first one $(\mathrm{H}: 6.4 \mathrm{~cm})$, preserving only the head of the female character wearing a tiara, was found in a pit, next to a brooch with an anchor shaped head (Fig. 4). ${ }^{8}$ The other one (H: $14.60 \mathrm{~cm}, \mathrm{~W} 9.50 \mathrm{~cm}$, thk: $\left.5.70 \mathrm{~cm}\right)$, almost complete, was excavated from a layer dated following mid of $2^{\text {nd }}$ century AD (Fig. 5). That brooch is a Cocis 20a type, being circulated between the middle of the $2^{\text {nd }}$ and the first decades of the $3^{\text {rd }}$ centuries AD. ${ }^{9}$ Taking into account the discovery context and the stratigraphy of the area, the first statuette may be dated to the second half of $2^{\text {nd }}$ century AD.

As for the location of their manufacturing workshop one can notice that there are both similarities and differences in depiction of the statuettes, which leads us to the idea that there were multiple workshops manufacturing them.

Ten such statuettes, either whole or fragmentary, were identified in Apulum, the greatest number of discoveries from Dacia province. In the current phase of research, it appears that in Apulum at least two workshops manufactured such pieces. The two statuettes from the old Cucuiu collection are produced by the same officina, yet they are different from the rest of the Apulum pieces, especially by the marking of the two oblique folds of the chlamys. Deities of the one in the National Museum of Transylvanian History have rendered hairstyle and beard (the god's case), also the hem of the mantle of the masculine character, by repeated incisions. Then, it is likely that the statuette (H: $16.3 \mathrm{~cm}$; W: $8.5 \mathrm{~cm}$ ) published by Alexandru Popa (Fig. 6) ${ }^{10}$ was made in the same workshop as that recently discovered east of colonia Aurelia Apulensis. The statuette from the villa suburbana of the spot named "Monolit", beside that was discovered west from the same Roman town in 2013, may represent variants manufactured in other workshops of Apulum. In reality, there are stylistic differences in the rendering manner of the hairstyle and vestments.

\footnotetext{
${ }^{1}$ GUdEA 1989, 513, no. 6, Pl. CVIII.

2 BUdAY 1911, 86, 89; GudEA 1989, 740, no. 1, Pl. CCLVI.

${ }^{3}$ Gudea 1989, 736-737, no. 3, Pl. CCLII, CCLIV.

${ }^{4}$ DFM 2006, no. 106; ANGHel et al. 2011, 55, Cat. Nr. 55.

${ }^{5}$ Moga-Ciobanu 2004, 625-627.

${ }^{6}$ Bounegru-Ota 2010, 429, fig. 3/3; ANGHel et al. 2011, 54, Cat. Nr. 54.

${ }^{7}$ Archaeological excavations were carried out by a team of archaeologists of the National Museum of Unification under the leader-
}

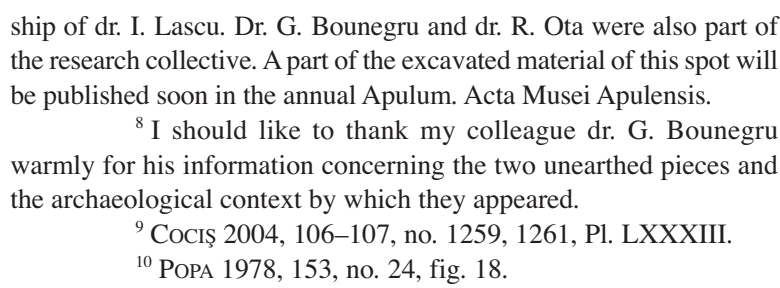

ship of dr. I. Lascu. Dr. G. Bounegru and dr. R. Ota were also part of the research collective. A part of the excavated material of this spot will be published soon in the annual Apulum. Acta Musei Apulensis.

${ }^{8}$ I should like to thank my colleague dr. G. Bounegru warmly for his information concerning the two unearthed pieces and the archaeological context by which they appeared.

${ }^{9}$ CocIș 2004, 106-107, no. 1259, 1261, Pl. LXXXIII.

${ }^{10}$ Popa 1978,153 , no. 24 , fig. 18. 


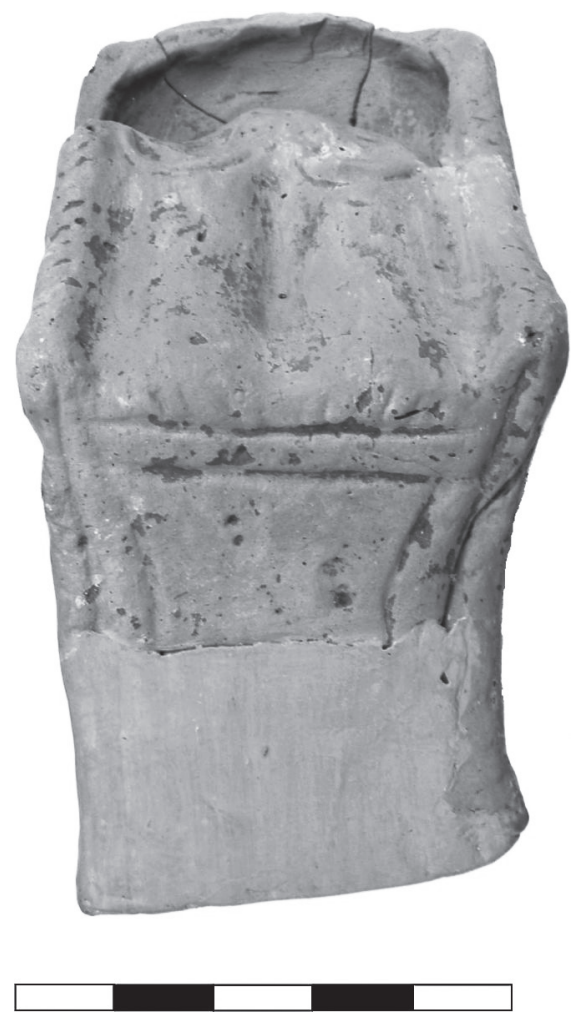

Fig. 1. Statuette of a paredros from a villa suburbana - south of Municipium Septimium Apulunse, west of Colonia Aurelia Apulensis (after ANGHEL et al. 2011, 55, Cat. Nr. 55)

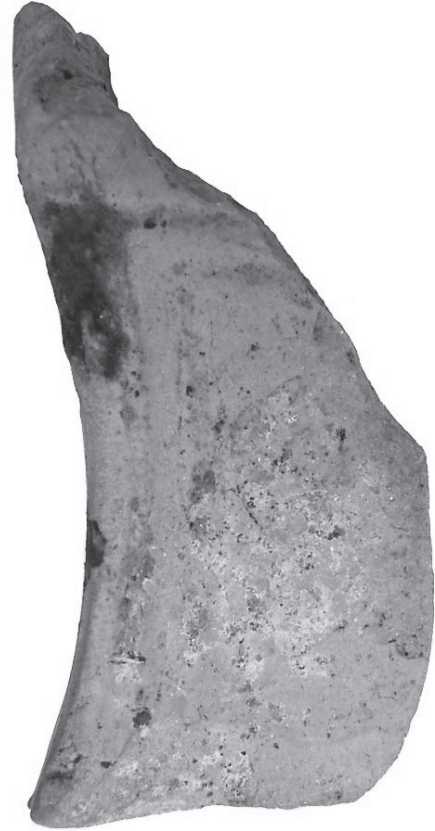

Fig. 2. Fragmentary statuette of a paredros (after ANGHEL et al. 2011, 54, Cat. Nr. 54)

Additionally, it is likely that some pieces had been manufactured in the same workshop, yet in different moulds. However, several common technical features are noticed in pieces from Apulum: the back of the chair has two bowing warps towards the heads of the characters, which form three knobs arranged along the edges and middle of throne's back; the male character is bearded, wearing a chlamys, and the female wears a semicircular tiara; the presence of a knob in relief dividing into two the rendering area of the characters; the throne's armrest are „woven”.

The statuette of Porolissum is poorly kept. The feminine character is on the left side, and the masculine on the right. ${ }^{11}$ A terracotta - provided us with only one drawing - coming from Potaissa is also similar, having the same arrangement of characters. ${ }^{12}$ It is difficult to say whether they come from the same workshop or not. Another two statuettes from Potaissa definitely were made by the same figlina. ${ }^{13}$ The two characters, the male on the right and the female on the left, have the same features in rendering the clothes and the upper edge of the back of the throne, which follows the line of the characters' heads. Bowings of the throne's back are inverse, by comparison with those identified on pieces of Apulum.

None of the place of discovery is known for any of the statuettes of Ulpia Traiana Sarmizegetusa. One of these renders two feminine characters, so it is not the topic for our investigation. It was depicted as two paredros, masculine and feminine, that have radial rendered hairstyle. ${ }^{14}$ From our point of view, it is only the incised decoration of the throne's back, and nothing more.

The hairstyle is distinctive, represented by several locks of barely noticeable hair. There are no published photographs of the second piece and the illustration is sketchy. For this reason, it has been excluded from the analysis. ${ }^{15}$

${ }^{11}$ Gudea 1989, 513, no. 6, Pl. CVIII.

${ }^{12}$ Ardevan-Rusu 1979, 392-393, Fig. 5, 9; Bărbulescu 1994, 115; CĂTINAȘ 2005, 151, no. 3, pl. 4.15.
${ }^{13}$ ARDEVAN-Rusu 1979, 392-393, Fig. 5, 9; Bărbulescu 1994, 115; CĂTINAŞ 2005, 151, no. 1-2, Pl. 4.13-14.

${ }^{14}$ Alicu et al. 1979, 121, no. 271, Pl. CXXXVI.

${ }^{15}$ Ibidem, 121, no. 272. 


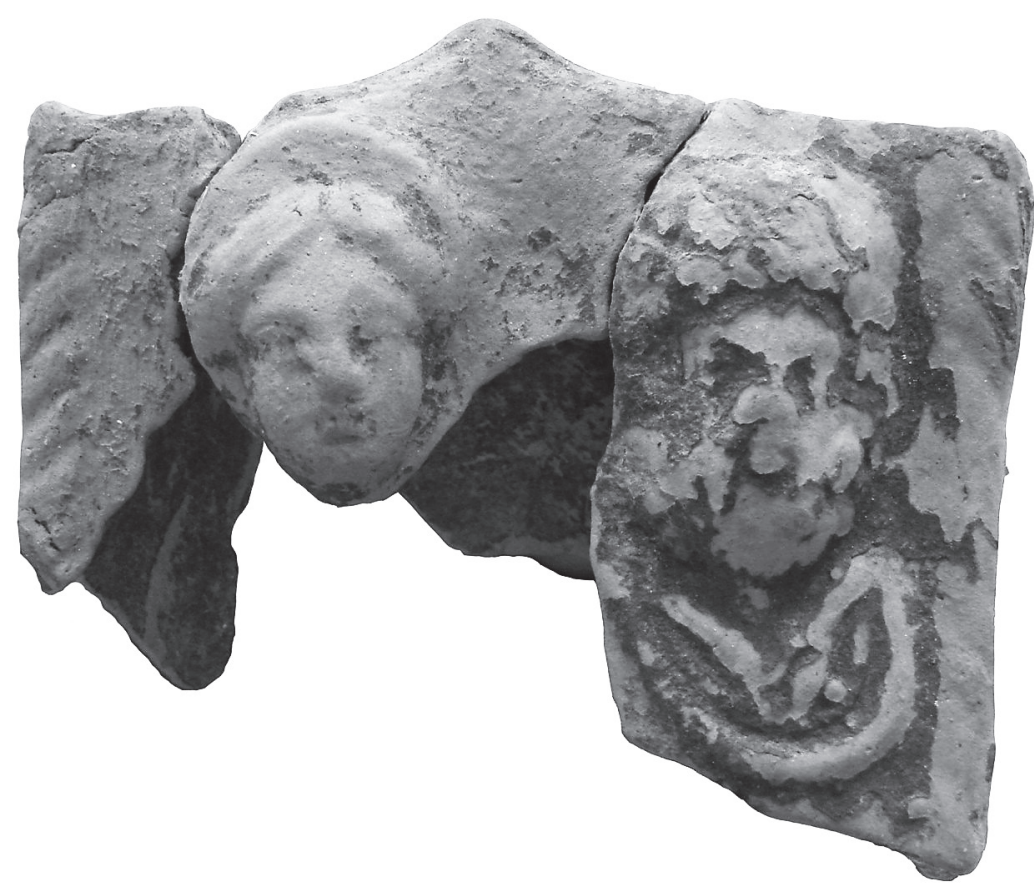

Fig. 3. Fragmentary statuette of a paredros from a villa suburbana - west of Colonia Aurelia Apulensis; unpublished

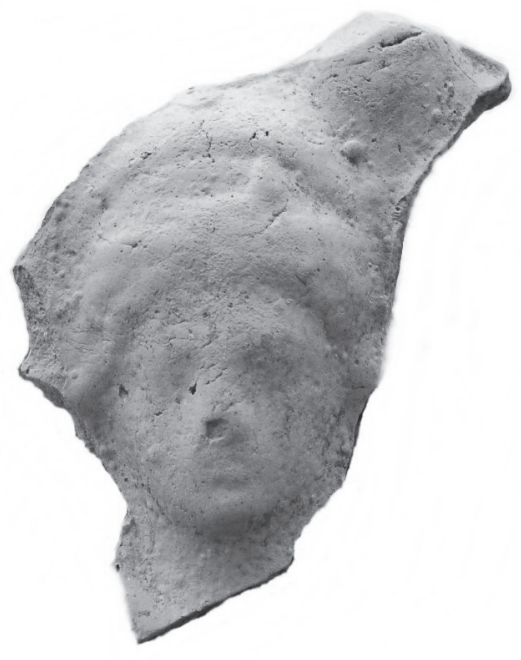

Fig. 4. Fragmentary statuette of a paredros from a villa suburbanaeast of Colonia Aurelia Apulensis; unpublished 
Two statuettes remain. In one of them, only the female character on the left is fully preserved while the male figure (unless it is also a goddess) is missing its head. ${ }^{16}$ The depiction is similarly sketchy. The armrests of the throne are decorated differently from other statuettes from Dacia. The final piece that can definitely be included as belonging to this type of representation ${ }^{17}$ is strikingly like at least two of the statuettes from Apulum..$^{18}$ It was probably manufactured in an urban centre near the banks of the Mureş River.

The large number of paredros discovered in Ulpia Traiana Sarmizegetusa suggests the existence of a workshop that manufactured them. ${ }^{19}$ Presumably, they produced figurines representing two female deities. Even if the missing character from the figurine from Ulpia Traiana Sarmizegetusa (inventory no. 445) is male, ${ }^{20}$ the piece would still belong to the iconographic type of interest here. This suggests that a coroplastic workshop producing the type of paredreos that depicted one male and one female figure also operated in this town. That said, in its current phase, research does not support the existence of statuette workshops in this urban centre.

\section{COMMENTS ON THE STATUETTES' SIGNIFICANCE}

Leading interpretations of the statuettes' significance must also be considered. Árpád Buday puts forward several hypotheses. From his point of view, the figurines may represent some members of the imperial family. Another interpretation is that the figures represent deities, a theory supported by the godlike couple Jupiter and Juno, discovered in Porolissum in the context of a dwelling that belonged to a veteran of the military unit deployed there. Considering that Juno was, amongst other things, the goddess of marriage, Buday made a connection between the right of veterans to start a family and the protection offered by the goddess. ${ }^{21}$

Nicolae Igna, in a study about Aesculapius and Hygia in Dacia Superior, advances the idea that these statuettes might depict the gods of medicine,,$^{22}$ probably because of the numerous epigraphic and sculptural attestations from Dacia Superior, especially from Apulum. András Alföldi interprets them as belonging either to Jupiter and Juno, or to Pluto and Proserpine. ${ }^{23}$ In a monograph on the history of Transylvania during ancient times, Constantin Daicoviciu hypothesizes that these sitting deities may depict Dacian deities rendered in interpretatio romana. ${ }^{24}$ Magdalena Jude and Constantin Pop interpret them as probably being depictions of Jupiter and Juno. ${ }^{25}$ In a study of votive terracottas from Apulum, Al. Popa mainly focuses on these statuettes. He mentions five pieces, either whole or fragmentary, and concludes that it is difficult to state exactly what deities they refer to. He inclines, however, towards Jupiter and Juno, not excluding the possibility that the figurines may also represent either Dacian deities or the Roman deities Aesculapus and Hygia or Pluto and Proserpine. ${ }^{26}$ Dorin Alicu, C. Pop, and Volker Wollmann agree with the theory formulated by C. Daicoviciu. ${ }^{27}$ Ion Miclea and Radu Florescu consider them to be Penates, household gods,$^{28}$ but do not take into consideration that there are two female characters. N. Gudea interprets the statuette from Porolissum as a depiction of Zeus and Hera. ${ }^{29}$ Mihai Bărbulescu believes that the statuette might represent Domnus and Domna, or possibly Dis Pater and Proserpine. ${ }^{30}$ The godlike couple Dominus and Domina, ${ }^{31}$ whose origin and significance is not clear, are more frequently found in inscriptions from the $3^{\text {rd }}-4^{\text {th }}$ centuries $A D$ in the shortened form Domnus-Domna. ${ }^{32} \mathrm{~A}$ fragmentary votive terracotta discovered in Cristeşti, an important ceramic centre in Dacia's rural area, includes part of an inscription that suggests the two figures may represent this particular pair of deities..$^{33} \mathrm{~A}$ sanctuary to them was identified in Ulpia Traiana Sarmizegetusa. ${ }^{34} \mathrm{C}$. Pop's study of innova-

${ }^{16}$ Ibidem, 120, no. 269, Pl. CXXXVI.

${ }^{17}$ Ibidem, 121, no. 270, Pl. CXXXVI.

${ }^{18}$ One published by A1. Popa (PopA 1978, 153, no. 24, fig. 18.) and another one, discovered recently in 2015, east of the Colonia Aurelia Apulensis.

${ }^{19}$ STtefanescu-Onițiu 2008, 363

${ }^{20}$ Alicu et al. 1979, no. 269.

${ }^{21}$ BudAY 1911, 86, 89.

${ }^{22}$ IGNA 1935, 69-71, Fig. 31.

${ }^{23}$ AlFÖLDI 1940, 33.

${ }^{24}$ DAICOVICIU 1945, 154.

${ }^{25}$ JudE-Pop 1973, 34, no. 4, Pl. XXXII.4
${ }^{26}$ PoPA $1978,153-154,158$, no. $21-25$.

${ }^{27}$ Alicu et al. 1979, 22.

${ }^{28}$ Miclea-FloRescu 1980, 69, nr. 51.

${ }^{29}$ Gudea 1989, 513, no. 6, Pl. CVIII.

${ }^{30}$ BĂRBULESCU 1994, 115, 161.

${ }^{31}$ It seems that this only refers to local gods, of Danubian origin. They are attested epigraphically by 11 votive monuments that are scattered throughout Dacia, Pannonia, Moesia and Dalmatia. See: NEMETI 2012, 84-88.

${ }^{32}$ PÁNCZÉl 2010, 77, fn 2.

${ }^{33}$ Ibidem, 77-84.

${ }^{34}$ FIEDLER-HÖPKEN 2010, 327-341. 


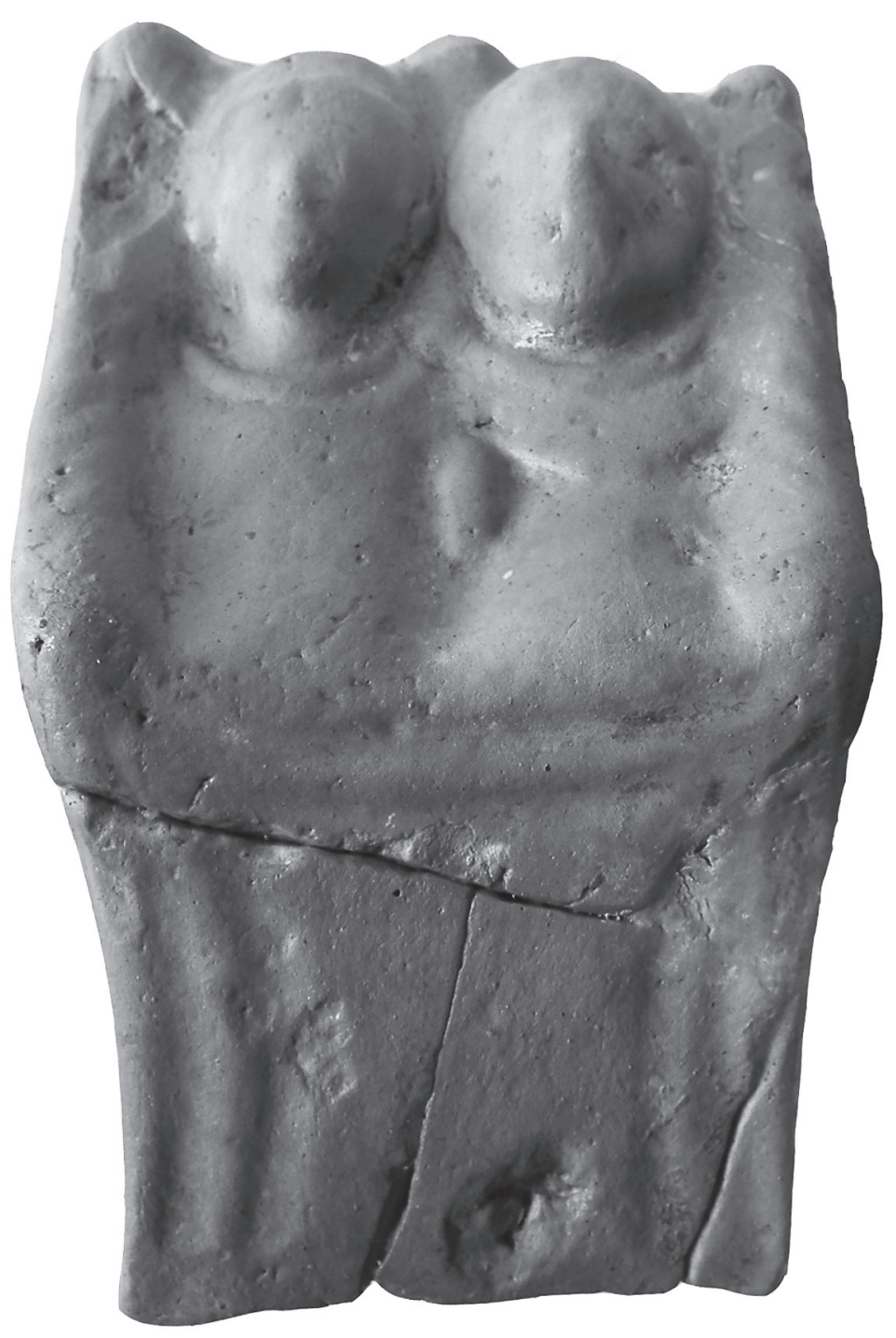

Fig. 5. Statuette of a paredros from a villa suburbana - east of Colonia Aurelia Apulensis; unpublished

tions in provincial art from Dacia also analyses this type of votive terracotta. He notes that these figurines spread only through intra-Carpathian Dacia. He hypothesises that they depict local Dacian deities shown as interpretatio romana. ${ }^{35}$ In effect it is a reconfirmation of the theory advanced by C. Daicoviciu in 1945.

Mihai Gramatopol draws a parallel with the paredros discovered in the Tomis area. One depicts Demeter and Koré and the other one, harpies. He also includes statuettes found on the western shore of Pontus Euxinus (and even from southern Ukraine), saying that figurines depicting paredros (male and female) from Dacia might depict the god-like couple Pluto and Proserpine. They may have had eschatological significance as funerary offerings. ${ }^{36}$

${ }^{35}$ Pop 1999-2000, 177.
${ }^{36}$ Gramatopol-CrăCIUNESCU 1969, 47, no. 74, pl. III/10; Gramatopol 1982a, 161, Fig. 44c-d; Gramatopol 1982b, 191, pl. XI.7,9; GRAMATOPOL 2000, 186, il. 59. 


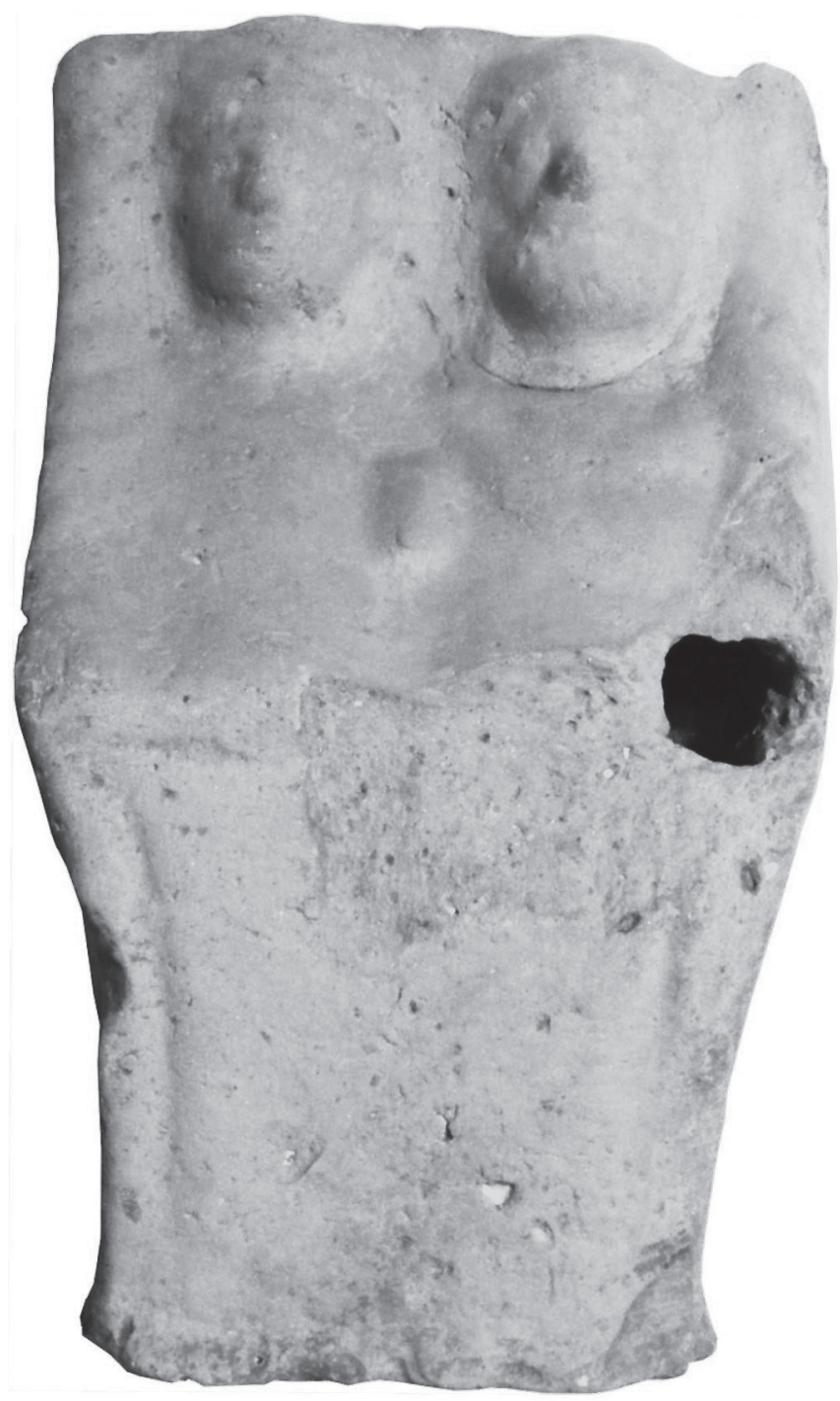

Fig. 6. Statuette of a paredros from Apulum (after ANGHEL et al. 2011, 54, Cat. Nr. 53)

Turning his attention to the piece from Ulpia Traiana Sarmizegetusa, where only the head of the female character was preserved, the same author thinks that it may depict an imperial couple, ${ }^{37}$ as previously noted by Á. Buday in 1911. ${ }^{38}$ Statuettes depicting couples of female paredros were discovered in a funerary environment from Tomis and Apollonia as well as in another burial context in Odessos. ${ }^{39}$ Statuettes from Durostorum ${ }^{40}$ and Tomis depict the harpies. A paredros depicting two female characters, instead of one male and one female figure, was retrieved from an inhumation grave from Oescus. ${ }^{41}$

\footnotetext{
${ }^{37}$ Gramatopol 1982b, 191, pl. XI.9.

${ }^{38}$ BUDAY 1911, 86, 89.

${ }^{39}$ ŞTIRBULESCU 2004, 227-228, 230, Fig. 1-1a.
}

${ }^{40}$ Ibidem, 228, Fig. 1-1a.
${ }^{41}$ KaZAROw 1932, 129-130, Fig. 123.

Acta Archaeologica Academiae Scientiarum Hungaricae 68, 2017 
Clay statuettes with the image of two seated characters, male and female, appear in the Etruscan and Latin environment starting in the $5^{\text {th }}$ century BC. They also appear in the Greek world. In southern Etruria, they are found in Crotona, Veii, Tarquinia, Latium, Rome, Praeneste, and Lavinium. They were produced over a long time period, between the $5^{\text {th }}$ century BC and beginning of the $1^{\text {st }}$ century BC. ${ }^{42}$ They were discovered in authentic votive deposits placed near temples. ${ }^{43}$ Considering that sometimes the female character is shown holding a child in her arms, the posture suggests the concepts of maternity, fecundity, and the domestic environment.

Sorin Nemeti believes that such statuettes are not unique to Dacia. They can be found in different areas of the Empire with their iconography adapted to local requirements. A good example is a statuette found in Gaul, called a "couple edduén". ${ }^{44}$ It appears that the Gallic statuettes served a similar function to those discovered in Etruria and Latium.

\section{CONCLUSIONS}

Several conclusions may be drawn from this analysis. At this point, based on all the bibliographical information and latest archaeological discoveries (from Apulum), ten statuettes with male and female paredros are known. All were discovered in Dacia Superior, in the most Romanized and urbanized area of the province, along the line comprising Ulpia Traiana Sarmizegetusa-Apulum-Potaissa-Porolissum. It appears that only one figurine from Ulpia Traiana Sarmizegetusa can be used in this study from an iconographic point of view. ${ }^{45}$ Those figurines from Senerăuş (Mureş county), Micia, as well as statuettes held in museum collections in Cluj-Napoca (except for one discovered in Apulum, which has been published), Bucharest, and Budapest could not be analysed, because they have only been mentioned, without being published in a specialised work. ${ }^{46}$

This analysis was based only on published pieces and finds that were discovered in excavations in Apulum. Those finds that could not be viewed and only mentioned in various publications, were excluded. Only definite representations were referred to, including clay statuettes of seated deities (male and female) identified in Potaissa (three), Ulpia Traiana Sarmizegetusa (one), and Porolissum (one). The main centre of their manufacturing was Apulum, where two thirds of the discoveries were made. In total, there are 14 definite representations from Dacia Superior and one from Dacia Porolissensis. More than $90 \%$ of the statuettes were found in urban centres, mainly in those defended by a legionary fortress or auxiliary fort. That said, none were found within a Roman military encampment. Similarly, no statuettes of this type were found in graves.

Whom do these statuettes depict? It is difficult to offer a single answer. It cannot be assumed that they are Dacian deities because these pieces were made exclusively in urban centres, ${ }^{47}$ where official cults were well developed and commonly worshipped. In addition, the defeated Dacian population was almost non-existent in these towns. Most importantly, the ancient aristocracy from Decebal's kingdom did not survive. ${ }^{48}$

There was a high degree of Romanisation which was implemented quickly over the course of several decades ${ }^{49}$ Evidence of this process can be seen in the approximately 3500 Latin inscriptions carved in stone, which demonstrates that Latin represented the lingua franca for conquered native populations, as well as various categories of colonist. ${ }^{50}$ Contrary to other provinces of the Empire such as Africa, Britannia, Gallia, Hispania, Lusitania, and Germania, where numerous ancient deities survived the Roman conquest, the old Dacian deities are not found in the pantheon worshipped in the Trajanic province..$^{51}$

\footnotetext{
${ }^{42}$ DUCATÉ 2000, 38.

${ }^{43}$ Ibidem, 38-39.

${ }^{44}$ NEMETI 2005, 187, fn 488.

${ }^{45}$ Alicu et al. 1979, 121, no. 270, Pl. CXXXVI; MCDR, nr. inv. 446

${ }^{46}$ National Museum of Transylvanian History (three copies), National Museum of Romanian History (one copy), Magyar Nemzeti Múzeum (Hungarian National Museum; one copy). See: Rusu-Pescaru-Pop 2001-2002, 198; Pop 1999-2000, 177.

${ }^{47}$ If the figurine from Senerăuş depicts a paredros, male and female, then this represents the only discovery of its kind in a rural
}

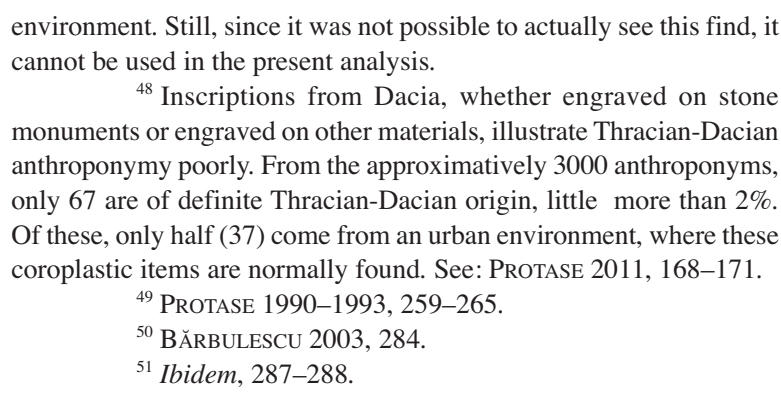

environment. Still, since it was not possible to actually see this find, it cannot be used in the present analysis.

${ }^{48}$ Inscriptions from Dacia, whether engraved on stone monuments or engraved on other materials, illustrate Thracian-Dacian anthroponymy poorly. From the approximatively 3000 anthroponyms, only 67 are of definite Thracian-Dacian origin, little more than $2 \%$. Of these, only half (37) come from an urban environment, where these coroplastic items are normally found. See: PROTASE 2011, 168-171.

${ }^{49}$ Protase 1990-1993, 259-265.

${ }^{50}$ BăRBULESCU 2003, 284.

${ }^{51}$ Ibidem, 287-288. 
Usually, the local deities of defeated populations were tolerated, adopted, and included in the provincial pantheon. Contrary to this custom, the Roman state behaved differently towards the clerical aristocracy and Dacian sanctuaries, which it brutally eliminated. ${ }^{52}$ Five years ago, specialists were more inclined to attribute these representations to infernal deities ${ }^{53}$ because some statues and reliefs were made of marble and bronze. They were discovered in Apulum, ${ }^{54}$ Ulpia Traiana Sarmizegetusa, ${ }^{55}$ Tomis $^{56}$ and Mainz. ${ }^{57}$ However, their absence from graves ${ }^{58}$ runs contrary to that hypothesis. Worshippers would have had to feel comfortable with the deities of Hades in their homes, in familiar environments, and in domestic lararia for the statuettes for these statuettes to represent deities associated with death. The latter seems very unlikely, if not impossible.

The statuettes more than likely demonstrate the attachment shown by provincials to imperial governance through the worship of the cult of Jupiter and Juno, the official deities of the Roman state. The sober depiction, the static quality of the characters, frontalism, their standardized height, and the resemblance of the male character to depictions of Jupiter (the serious expression and rigid attitude) suggest that these cheap votive items are representations of the god-like couple Jupiter and Juno. In Apulum alone there are 18 statues and statuettes of Jupiter Verospi, ${ }^{59}$ two of Jupiter Fulminans, ${ }^{60}$ and over 100 inscriptions dedicated to this deity. ${ }^{61}$ A votive relief of Jupiter and his paredros is preserved in the collections of the National Museum of the Union in Alba Iulia, a rare image of the divine pair from Dacia. ${ }^{62}$ Similarly, the presence of Juno is also connected to the protection of women, home, births and marriages. ${ }^{63}$ These statuettes represent offerings made especially in lararia of Roman houses and likely protected everything related to family and everyday life.

\section{REFERENCES}

BHAUT

ALFÖLDI 1940

AliCU et al. 1979

ANGHEL et al. 2011

ARDEVAN-RUSU 1979

BĂLUȚĂ 1976

BĂLUŢĂ 1980

BĂLUŢĂ 2002

BĂRBULESCU 1994

BĂRBULESCU 2003

BORDENACHE 1969

BOUNEGRU-OTA 2010
= Bibliotheca Historica et Archaeologica Universitatis Timisiensis, Timişoara.

= A. ALFöLDI: Daci e romani in Transilvania. BudAPEST 1940.

= D. Alicu -C. Pop-V. Wollmann: Figured Monuments from Ulpia Traiana Sarmizegetusa. BAR IntSer 55. Sarmizegetusa monographs 2. Oxford 1979.

$=$ D. Anghel-R. OtA-G. Bounegru-I. LAscu: Coroplastica, medalioane şi tipare ceramice din colecţiile Muzeului Naţional al Unirii Alba Iulia [Roman Coroplastic, Ceramic Medaillons and Molds from the Collection of the National Museum of the Union Alba Iulia]. Alba Iulia 2011.

$=$ R. ARdEVAN-A. A. Rusu: Botár Imre şi colecţia sa de antichităţi [Imre Botár and his antiquity collection]. ActaMP 3 (1979) 387-410.

= C. L. BĂLUȚ̆ Alăci votive de la Apulum [Votive plaques from Apulum]. Apulum 14 (1976) 131-147.

= Cl. L. BĂLUŢĂ: Statui reprezentând pe Iupiter tronans descoperite la Apulum [Statues of Jupiter Tronans discovered at Apulum]. Apulum 18 (1980) 101-106.

= Cl. L. BĂLuŢĂ: Monumentul statuar cu Pluton şi Proserpina de la Apulum (Dacia) [The statuary monument of Pluto and Proserpina from Apulum (Dacia)]. Apulum 39 (2002) 301-307.

= M. BĂRBULESCU: Potaissa. Studiu monografic. Turda 1994.

= M. BĂRBULESCU: Interferenţe spirituale în Dacia romană [Spiritual Interferences in Roman Dacia]. Cluj-Napoca 2003. $2^{\text {nd }}$ edition.

$=$ G. BordEnACHE: Sculture greche e romane del Museo Nazionale di Antichità di Bucarest. Statue e rilievi di culto, elementi architettonici e decorative. I. Bucarest 1969.

= G. BounEgRU-R. OTA: Cercetări arheologice în canabele legiunii a XIII-a Gemina. Sectorul de nord-vest (str. Timotei Cipariu, nr. 25) [Archaeological researches int the canabae of legio XIII Gemina. North-western sector (25, Timotei Cipariu Str.)]. I. Apulum 47 (2010) 427-446.
Ibidem, 289-290

${ }^{53}$ OTA 2011, 8 .

${ }^{54}$ KÜNZL 1999, 561, Abb. 8-9; BĂLUŢă 2002, 301-306.

55 TÉGLÁs 1907, 369; Alicu et al. 1979, 18, pl. XXIV;

KüNZL 1999, 561, Abb. 4-7, Rusu-PeSCARU-Alicu 2000, 146.

${ }^{56}$ BordenACHE 1969, 82-83, nr. 162, Tav. LXX.162;

KÜNZL 1999, 561, Abb. 10.

${ }^{57}$ KÜNZL 1999, 557, Abb. 1-3.

${ }^{58}$ More than 1000 graves have been studied from Apulum.

See: ОTA 2009, 23-47; BouNEGRU 2011, 79-88.
59 ISAC 1974, 61-81; BĂLUŢă 1980, 101-106; TIMOFANОТА 2010, 251-267; ОТА 2013, 63-79.

${ }^{60}$ OTA 2007, 255-266.

${ }^{61}$ IDR III/5, 87-181, 510-512, no. 109-232, 703-705.

${ }^{62}$ BĂLuţă 1976, 132, fig. 2/2; OTA 2013, 69, Fig. 58. For an interesting paper about attestations of the Capitoline Triad in Dacia, see: NiCOLAE 2011, 291-305.

${ }^{63}$ Grimal 2001, 279; Ferrari 2003, 468. 
BOUNEGRU 2011

BUDAY 1911

CĂTINAȘ 2005

CoCIŞ 2004

DAICOVICIU 1945

DFM 2006

DuCATÉ 2000

FERRARI 2003

FIEDLER-HÖPKEN 2010

GRAMATOPOL-CRĂCIUNESCU 1969

GRAMATOPOL 1982a

GRAMATOPOL 1982b

GRAMATOPOL 2000

GRIMAL 2001

GudEA 1989

IDR III/5

IGNA 1935

ISAC 1974

JuDE-PoP 1973

KAZAROW 1932

KÜNZL 1999

MiClEA-FLORESCU 1980

Moga-Ciobanu 2004

NeMETI 2005

NEMETI 2012

NiCOLAE 2011

OTA 2007

OTA 2009

ОтА 2011

ОTA 2013

PÁNCZÉl 2010
= G. BounEGRU: Roman cemeteries from Apulum. Demarcation and chronology. In: Scripta classica. Radu Ardevan sexagenario dedicata. Eds.: I. Piso, V. Rusu-Bolindeţ, R. Varga, S. Mustaţă, L. Ruscu. Cluj-Napoca 2011, 79-88.

= Á. BudAY: Porolissumból - Fouilles faites au Porolissum. DolgCluj 2/1 (1911) 70-105.

= A. CĂTINAŞ: Plastica în lut de la Potaissa [The Roman clay statuettes from Potaissa]. In: Corona laurea. Studii în onoarea Luciei Ţeposu-Marinescu. Eds.: C. Muşeţeanu, M. Bărbulescu, D. Benea. Bucureşti 2005, 143-158.

= S. Cocış: Fibulele din Dacia romană - The Brooches from Roman Dacia. Cluj-Napoca 2004.

= C. DAicoviciu: La Transylvanie dans l'antiquité. Bucarest 1945.

= V. MogA (ed.): Alba Iulia Dealul Furcilor-Monolit, catalogul expoziţiei [Alba Iulia Dealul FurcilorMonolit, exhibition catalogue]. Alba Iulia 2006.

$=$ S. Ducaté: Un couple votif en terre cuite provenant de la région de Santa Severa (province de Rome). Latomus 59/1 (2000) 36-40.

= A. FERRARI: Dicționar de mitologie greacă și romană [Dictionary of Greek and Roman Mythology]. Iași 2003.

= M. FIEDLER-C. HöPKEN: Micul templu al marilor divinităţi: sanctuarul lui Domnus şi Domna din Sarmizegetusa [The small temple of great divinities: sanctuary od Domnus and Domna from Sarmizegetusa]. In: Studia Archaeologica et Historica in honorem Magistri Dorin Alicu. Eds.: V. Rusu-Bolindeț, T. Sălăgean, R. Varga. Cluj-Napoca 2010, 327-341.

= M. G Gramatopol-V. Crăciunescu: Les terres cuites antiques de la Collection Marie et dr. G. Severeanu du Musée d'Histoire de la ville Bucarest. RRHA 6 (1969) 35-68.

= M. GRAMATOPOL: Artă şi arheologie dacică şi romană [Dacian and Roman Art and Archaeology]. Bucureşti 1982.

= M. Gramatopol: Dacia antiqua. Perspective de istoria artei şi teoria culturii [Dacia antiqua. Perspectives of Art History and the Theory of Cult]. Bucureşti 1982.

= M. Gramatopol: Arta romană în România [Roman Art in Romania]. Bucureşti 2000.

= P. GRIMAL: Dicţionar de mitologie greacă şi romană [Dictionary of Greek and Roman Mythology]. Bucureşti 2001.

= N. GUDEA: Porolissum. Un complex daco-roman la marginea de nord a Imperiului Roman [Porolissum. A Dacian-Roman Complex on the Northern Border of the Roman Empire]. 1. ActaMP 13. Zalău 1989.

= I. PISO (ed.): Inscriptiones Daciae Romanae, Inscriptions d'Apulum. III/5. 1-2. Paris 2001.

= N. IGNA: Cultul lui Esculap şi al Higiei: cu specială privire la Dacia Superioară [The Cult of Aesculapius and Hygeia. A special view on Dacia Superior]. Biblioteca medico-istorică 8. Cluj-Napoca 1935.

= D. IsAC: Contribuţii la iconografia religioasă a Daciei romane. Iuppiter Verospi [Contributions to the religious iconography of Roman Dacia. Juppiter Verospi]. ActaMN 11 (1974) 61-81.

= M. JudE-C. Pop: Monumente sculpturale romane în Muzeul de Istorie Turda [Roman Sculptural Monuments in the Turda History Museum]. Turda 1973.

= G. I. KAZAROw: Antike Denkmäler in Bulgarien. IAI 6 (1930-1931) [1932] 117-135.

= E. KÜNZL: Eine Patrize für Votivreliefs an die Unterweltgötter aus Dakien. AKorr 29/4 (1999) 557-567.

= I. MiCLEA-R. FloRESCU: Daco-romanii. 1. Bucureşti 1980.

= V. Moga-R. Ciobanu: Septimius Asclepius Hermes, le medecin d'Apulum, dans une nouvelle inscription, recemment decouverte. In: Orbis Antiquus. Studia in honorem Ioannis Pisonis. Eds. L. Ruscu, C. Ciongradi, R. Ardevan, C. Roman, C. Găzdac. Cluj-Napoca 2004, 625-630.

$=$ S. NEMETI: Sincretismul religios în Dacia romană [Religious Syncretism in Roman Dacia]. Publicaţiile Institutului de Studii clasice/Universitatea „Babes-Bolyai” Cluj-Napoca 5. Cluj-Napoca 2005.

= S. NeMETI: Dialoguri păgâne. Formule votive şi limbaj figurat în Dacia romană [Pagan Dialogues. Votive formulas and figurative language in Roman Dacia]. Iaşi 2012.

= M. C. NicolaE: The Capitoline Triad in Roman Dacia. Peuce 9 (2011) 291-305.

$=$ R. OTA: Iupiter fulminans în iconografia religioasă apulensă [Iupiter Fulminans in religious iconography in Apulum]. Pontica 40 (2007) 255-267.

$=\mathrm{R}$. ОтА: Some observations on the latest archaeological researches carried out in the Roman necropolis from Apulum (Alba Iulia) - „Dealul Furcilor - Podei”. EphN 19 (2009) 23-47.

$=$ R. ОTA: Coroplastica, medalioane şi tipare ceramice din colecţiile Muzeului Naţional al Unirii Alba Iulia [Roman coroplastic, ceramic medaillons and molds from the collection of the National $\mathrm{Mu}$ seum of the Union Alba Iulia]. In: ANGHEL et al. 2011, 5-10.

$=$ R. OTA: Remarks on the stone statues of Jupiter in Dacia. In: Jupiter on Your Side. Gods and Humans in Antiquity in the Lower Danube Area. Ed. C. G. Alexandrescu. Bucharest 2013, 63-79.

= S. P. PÁnCZÉL: Domina and Dominus from Cristeşti (Mureş county). Marisia 30 (2010) 77-84. 
PoP 1999-2000

POPA 1978

PROTASE 1990-1993

PROTASE 2011

Rusu-Pescaru-Alicu 2000

Rusu-PESCARU-PoP 2001-2002

ŞTEFANESCU-ONIŢIU 2008

ŞTIRBULESCU 2004

TÉGLÁs 1907

TIMOFAN-OTA 2010
= C. PoP: Arta provincială a Daciei romane. Particularităţi novatoare [Provincial art in Roman Dacia. Innovating peculiarities]. EphN 9-10 (1999-2000) 169-179.

= Al. PopA: Teracote cu caracter votiv de la Apulum [Votive terracottas from Apulum]. Apulum 16 (1978) 149-160.

= D. Protase: Procesul de romanizare şi dăinuirea romanităţii în Dacia [Romanization and the perpetuation in the Romanization of Dacia]. Apulum 27-30 (1990-1993) 259-268.

= D. Protase: L'anthroponomastique thraco-dace et l'origine ethnique des porteurs dans les inscriptions de la Dacie romaine. Quelques observations. In: D. Protase: Orizonturi daco-romane. III. Cluj-Napoca, 2011, 168-175.

= A. Rusu-Pescaru-D. Alicu: Templele romane din Dacia [Roman Temples from Dacia]. I. Deva 2000.

= A. Rusu-PescARU-C. PoP: Monumente figurate descoperite la Micia [Figurative monuments dicovered in Micia]. Sargetia 30 (2001-2002) 195-201.

= A. ŞTEFANESCU-ONIŢıU: Producţia locală de statuete de teracotă în Dacia Romană [Local production of terracotta statuettes in Roman Dacia]. BHAUT 9 (2008) 362-376.

= C. ŞTIRBULESCU: Considerations on terracotta figurines from Durostorum. EDR 12/1 (2004) 227-241.

= G. TÉGLÁs: Újabb adalék a Sarmizegetusai alvilági cultus történetéhez [Newer data to the history of infernal cult in Sarmisegetusa]. ArchÉrt 27 (1907) 368-370.

= A. Timofan- R. OtAA: Capul unei statui de cult aparţinând lui Iupiter tronans descoperit la Apulum [A cult statue head belonging to Jupiter Tronans discovered in Apulum]. Pontica 43 (2010) 251-266. 